\title{
Buoyancy Regulation in a Strain of Microcystis
}

\author{
By R. H. THOMAS AND A. E. WALSBY* \\ Department of Botany, University of Bristol, Bristol BS8 IUG, UK
}

(Received 25 July 1984)

\begin{abstract}
A strain of the gas-vacuolate cyanobacterium Microcystis was found to float in cultures grown at low light intensities and to sink in those grown at high intensities. The loss of buoyancy that occurred within 1 to $5 \mathrm{~h}$ on increasing the photon flux density from 10 to $100 \mu \mathrm{mol} \mathrm{m}^{-2} \mathrm{~s}^{-1}$ was investigated by centrifuging the cell suspensions in a horizontally placed capillary with a rectangular cross-section, and then separately counting the floating cells under the upper tube surface and sinking cells on the lower surface. Buoyancy loss was not accompanied by loss of gas vesicles, as occurs in some other planktonic cyanobacteria, but was caused by a relative increase in dry matter, principally carbohydrate, without a corresponding increase in gas vesicles. The increase in light intensity gave an increase in cell turgor pressure but this was insufficient to collapse the strong gas vesicles present in this strain, which had a median critical pressure of $0.75 \mathrm{MPa}(7.5$ bar $)$.
\end{abstract}

\section{INTRODUCTION}

A number of gas-vacuolate, planktonic cyanobacteria have been shown to regulate their buoyancy according to light intensity. In low light intensity they become positively buoyant and float up, while in high intensity they become negatively buoyant and sink (Walsby, 1972). This response enables some planktonic forms to maintain themselves at a particular depth in a stratified lake (see Fogg \& Walsby, 1971, and Table 5 of Reynolds \& Walsby, 1975) while others, by forming rapidly moving colonies, use the same response to perform daily migrations to and from the lake surface (Konopka et al., 1978; Walsby et al., 1983a). The buoyancy of these organisms is provided by their gas vacuoles (Klebahn, 1895), which comprise aggregates of hollow cylindrical structures called gas vesicles (Bowen \& Jensen, 1965). In order to float a cell must possess sufficient gas vesicles to negate the excess density resulting from heavy substances such as carbohydrate and protein. Buoyancy regulation can then be achieved by varying the respective rates at which cell materials and intact gas vesicles are produced and destroyed (Walsby, 1970, 1972). Two mechanisms of light-mediated gas vacuole regulation were proposed; the collapse of gas vesicles by rising cell turgor pressure and the dilution of gas vesicles by cell growth.

A gas vesicle is a rigid, brittle structure that collapses irreversibly to a flattened envelope when subjected to a certain pressure known as its critical pressure. The critical pressures of the many gas vesicles within a single cell or population of cells vary in a predictable fashion about a welldefined median value. In Anabaena flos-aquae, where the median value is $0.6 \mathrm{MPa}(6 \mathrm{bar})$, the cell turgor pressure rises in high light intensities to $0.45 \mathrm{MPa}$ or more and, exceeding the critical pressures of the weakest gas vesicles, causes their collapse (Walsby, 1971; Dinsdale \& Walsby, 1972). The volume of gas vesicles lost, measured directly by a compression tube device, has been shown to account for the accompanying change in cell density, and this explains why the cells sink (Oliver \& Walsby, 1984). Similar responses are likely to occur in other species of Anabaena, Gloeotrichia (E. M. Allison \& A. E. Walsby, unpublished), Nostoc (Armstrong et al., 1983) and Aphanizomenon (Konopka et al., 1978), all of which have rather weak gas vesicles that can be collapsed by a moderate turgor pressure rise. In Anabaena the turgor rise is caused partly by the rise in osmotically active products of photosynthesis (Grant \& Walsby, 1977) and partly by the light-stimulated uptake of potassium ions (Allison \& Walsby, 1981). 
Buoyancy in a red-coloured strain of Oscillatoria agardhii is regulated by the other mechanism. Cell turgor pressure does rise when the organism is exposed to increased light intensity but the gas vesicles, which are considerably stronger than those in Anabaena, are not collapsed (Walsby et al., 1983a). Instead, gas vesicle production ceases and the existing gas vesicles are diluted out by cell growth (Utkilen $e t$ al., 1985). The cells may also preferentially accumulate carbohydrate which, being denser than other components such as protein, accelerates the buoyancy loss. This mechanism of buoyancy regulation may also occur in other cyanobacteria such as Trichodesmium, where the gas vesicles are much stronger (Walsby, 1978), and Dactylococcopsis, a halophile unable to develop high turgor pressure (Walsby et al., 1983b).

Microcystis is perhaps the principal nuisance cyanobacterium of temperate lakes and reservoirs; it forms noxious, and sometimes toxic water-blooms (Fogg, 1969; Carmichael, 1981). It is a gas-vacuolate unicellular organism that forms colonies in natural conditions. For hydromechanical reasons the colonies float or sink much more rapidly than single cells and they are therefore able to perform rapid vertical migrations (Reynolds \& Walsby, 1975). Dinsdale \& Walsby (1972) observed that colonies of Microcystis, collected from a reservoir at Staines (Surrey, England), lost buoyancy when exposed to high light intensity. Ganf (1974) and Ganf \& Oliver (1982) found that Microcystis populations daily produced sub-surface maxima in a manner suggesting that the colonies were avoiding high irradiance at the water surface by changing their buoyancy. Reynolds (1973) provided evidence that during calm periods Microcystis was able to stratify at a depth of several metres in Crose Mere (Shropshire, England). Changes of buoyancy of the organism were correlated with turgor pressure changes in a way which suggested that buoyancy was regulated by the mechanism of gas vesicle collapse by turgor pressure rise, but direct proof of this was not provided. Reynolds et al. (1981) found a correlation between the carbohydrate content and the density of cells whose gas vesicles had been collapsed, in natural populations of Microcystis in Blelham Tarn (English Lake District) during July to September 1978. They considered that the carbohydrate content might therefore affect the overall buoyancy of the gas-vacuolate colonies, and perhaps contribute to the sinking of colonies that was observed during the late autumn. Oliver $e$ al. (1985) have shown that there is in fact a decrease in carbohydrate content of Microcystis in this lake during autumn and that the loss of buoyancy then is caused by co-precipitation of the colonies with an iron-containing colloid. It is possible, however, that carbohydrate accumulation might account for buoyancy losses of colonies earlier in the summer period.

Some previous studies of gas vesicle changes in a strain of Microcystis aeruginosa, NRC-1, were made by Lehmann \& Jost (1971). By counting intact gas vesicles isolated from lysed cells, they demonstrated that the number decreased from over 8000 to less than 5000 per cell, after inoculation and growth in fresh medium. They proposed that the relative decrease in gas vesicle content was caused by dilution through cell growth because it seemed 'unlikely' that existing gas vesicles disappeared by collapse. This possibility was not, however, investigated directly. Walsby (1972) pointed out that the fall in gas vesicle content might have been a direct response to the higher light intensity that would exist in the newly established culture. Lehmann \& Wiencke (1980) subsequently demonstrated that when cells of the same strain were transferred from mineral culture medium to distilled water $80 \%$ of the gas vesicles were lost within $24 \mathrm{~h}$, though the mechanism of the disappearance was unknown.

In this paper we describe an investigation into the buoyancy regulation by a strain of Microcystis, using a new method for determining the buoyancy state of very small microorganisms in a short time. We have demonstrated that loss of buoyancy is caused by the relative decrease in gas vesicle content due to accumulation of other cell components and we have investigated whether gas vesicles can be regulated by turgor pressure in this and some other strains of Microcystis.

\section{METHODS}

Cultures. Several strains of Microcystis were investigated. (Rippka et al., 1979, have discussed the possible inclusion of the genus Microcystis in Synechocystis.) All of the strains contained gas vesicles. With one exception, the Blelham strain (provided by G. Jaworski, Freshwater Biological Association Ambleside, Cumbria, England), 
which produced small colonies, the different strains grew as separate unicells in the culture medium used, BG-11 of Stanier et al. (1971). Professor J. N. Eloff kindly provided the following strains from his collection at the University of the Orange Free State, Bloemfontein, South Africa: UV-001 (= NRC-1 from the National Research Council of Canada); UV-006, isolated from Hartebeesport Dam, near Pretoria (Kruger \& Eloff, 1977); UV-009; UV-010; UV-017; and strains PCC 7806 and 7820 from the Pasteur Culture Collection, Paris, France. The most detailed studies were performed on the strain from the Bristol Cyanobacteria Collection, Microcystis BC 84/1, which was isolated by us from a contaminant in a culture of Gloeotrichia echinulata CCAP 1432/1, and grown at $20^{\circ} \mathrm{C}$ under continuous illumination of $10 \mu \mathrm{mol} \mathrm{m} \mathrm{m}^{-2} \mathrm{~s}^{-1}$. Higher photon flux densities, of $100 \mu \mathrm{mol} \mathrm{m}^{-2} \mathrm{~s}^{-1}$ and more, were obtained in glass-bottomed waterbaths situated over two $20 \mathrm{~W}$ white light fluorescent tubes.

Buoyancy determination. The percentage of floating cells in a culture was estimated by two related methods. In the first, samples of the cell suspension were pipetted under the coverslip of a haemocytometer slide (depth $200 \mu \mathrm{m})$. The numbers of cells floating under the coverslip and sinking onto the platform of the slide were determined by counting in different focal planes, after leaving the cells for long enough to settle up or down to their equilibrium position, as described by Walsby \& Booker (1980). In the second method, a Camlab (Nuffield Road, Cambridge, England) Microslide - a flattened glass microcapillary tube, rectangular in cross-section, measuring on the inside $0.2 \mathrm{~mm}$ deep by $2.0 \mathrm{~mm}$ wide, and $50 \mathrm{~mm}$ long - was filled with the cell suspension by capillary rise. The ends were sealed with Paraplast paraffin and plastic polymer embedding wax (Lancer, Oxford, England), melted with a warm soldering iron, which also served to attach the Microslide, flat side down, to a microscope slide. The slide was placed on the flat base of a $98 \mathrm{~mm}$ diameter centrifuge bucket in an MSE Coolspin centrifuge with a swing-out head, and was centrifuged at 800 r.p.m., generating an acceleration of $1860 \mathrm{~m} \mathrm{~s}^{-2}(190 \mathrm{~g})$ for $2 \mathrm{~min}$. The Microslide was then examined under a phase-contrast illuminated microscope at a magnification of $400 \times$. The cells within one eyepiece grid field, seen floating against the upper surface, were counted; the microscope was then refocused on the bottom surface to count the sinking cells. This procedure was repeated at least six times at different fields along the Microslide until a minimum of 500 cells had been counted.

Measurements of gas vesicles and cell density. The pressure required to collapse gas vesicles in turgid cells, suspended in culture medium, and flaccid cells, suspended in medium containing $0.5 \mathrm{M}$-sucrose, was determined by turbidity measurements in a pressure-nephelometer (Walsby, 1973) as described by Walsby (1980). The volume occupied by gas vesicle gas space in cell suspensions (of volume $2.63 \mathrm{ml}$ ) was measured directly from the volume change following momentary application of a pressure of $1.4 \mathrm{MPa}$, using a capillary compression tube (Walsby, 1982) fitted with a thermostatted water jacket.

The density of the cells, after pressurizing to collapse their gas vesicles, was measured by centrifuging on to previously prepared continuous gradients of Percoll (Oliver et al., 1981 ; Oliver \& Walsby, 1984). Shallow gradients were produced by centrifuging suspensions of 20,30 , or $40 \%(\mathrm{v} / \mathrm{v})$ Percoll in BG-11 medium for $18 \mathrm{~min}$ at $3.9 \times$ $10^{5} \mathrm{~m} \mathrm{~s}^{-2}\left(4 \times 10^{4} \mathrm{~g}\right)$ and $20^{\circ} \mathrm{C}$. Suitable gradients, which had a slope of about $0.6 \mathrm{~kg} \mathrm{~m}^{-3}$ per mm over the required density range, produced a clearly visible layer of Microcystis cells. The density of this layer, determined by sinking sample droplets to their equilibrium position on a kerosene-carbon tetrachloride density gradient (Wolff, 1975) between densities of $970-1100 \mathrm{~kg} \mathrm{~m}^{-3}$, was taken as equal to the density of the cells.

Measurement of cell constituents. Dry weights were determined by filtering $5 \mathrm{ml}$ samples of cultures with predried $\left(105^{\circ} \mathrm{C}\right)$ and weighed $25 \mathrm{~mm}$ diameter Whatman GF/C filters. The filters were then dried for $24 \mathrm{~h}$ and reweighed on a Cahn electrobalance. Protein was determined by the Folin-Ciocalteau reagent as described by Herbert et al. (1971) using the modifications of Oliver \& Walsby (1984). Carbohydrate was measured with the anthrone reagent (Herbert et al., 1971).

\section{RESULTS}

\section{Buoyancy changes}

Although all of the strains studied produced gas vacuoles not all of them became buoyant under the culture conditions used. J. N. Eloff and R. D. Simon, working on the strains from the PCC and UV collections, demonstrated that a number of them produced colonies, on agarsolidified medium, that frequently gave sectors containing cells that differed in size and gas vacuole content. Gas vacuole production was therefore an unstable character in these strains, perhaps associated with plasmid-borne characters. We found that one of these strains, PCC 7806, was buoyant when grown in low light intensity. On transfer to a higher intensity loss of buoyancy was noted. By using the haemocytometer method of measuring the proportion of floating and sinking cells it was demonstrated that $55 \%$ of the cells lost buoyancy after $2.5 \mathrm{~h}$ and $82 \%$ after $19 \mathrm{~h}$. This strain was one that produced large and small cells and it was found that the smaller cells did not sediment satisfactorily on the haemocytometer even after standing for over an hour. 
Further studies were concentrated on strain BC 84/1, which produced buoyant cells when grown in a low light intensity, a photon flux density of about $10 \mu \mathrm{mol} \mathrm{m}^{-2} \mathrm{~s}^{-1}$. Transfer to high intensity, $150 \mu \mathrm{mol} \mathrm{m}^{-2} \mathrm{~s}^{-1}$, resulted in loss of buoyancy within several hours, the time required depending on the initial state of buoyancy. Preliminary attempts to determine the speed of the buoyancy change were frustrated by the long time taken for the cells to settle up or down completely in the haemocytometer. Many of the cells remained suspended partway between the coverslip and slide after $2 \mathrm{~h}$. The reasons for this become clear if the Stokes equation is used to calculate the time taken by a $5 \mu \mathrm{m}$ diameter sphere to settle $200 \mu \mathrm{m}$, the depth of the haemocytometer chamber. When the density of the sphere exceeds that of the suspending water by $20 \mathrm{~kg} \mathrm{~m}^{-3}$ (a typical value for a cell without gas vacuoles) the time required is $0.2 \mathrm{~h}$, but for a sphere of $3 \mu \mathrm{m}$ diameter (the smallest cells) this rises to $0.5 \mathrm{~h}$. For gas-vacuolate cells with an excess density of, say, only $2 \mathrm{~kg} \mathrm{~m}^{-3}$ the time required is $2 \mathrm{~h}$ for the $5 \mu \mathrm{m}$ sphere and $5 \mathrm{~h}$ for the $3 \mu \mathrm{m}$ one.

By centrifuging cell suspensions in the Microslides the time required could be reduced in proportion to the centrifugal acceleration, so that, for example, for the pressurized $5 \mu \mathrm{m}$ cell it is only $4 \mathrm{~s}$ and for the $3 \mu \mathrm{m}$ cell of excess density $2 \mathrm{~kg} \mathrm{~m}^{-3}$ it is only $39 \mathrm{~s}$, when an acceleration of $1860 \mathrm{~m} \mathrm{~s}^{-2}(190 \mathrm{~g})$ is used. There is a possibility that gas vesicles might be collapsed by the pressure generated by centrifuging a column of water (Walsby, 1971). The pressure developed is given by $h \rho g$ where $h$ is the depth of the water $\left(2 \times 10^{-4} \mathrm{~m}\right.$ in the Microslide), $\rho$ is its density $\left(998 \mathrm{~kg} \mathrm{~m}^{-3}\right)$ and $g$ is the acceleration. When $g$ is $1470 \mathrm{~m} \mathrm{~s}^{-2}$ the pressure developed is only $371 \mathrm{~Pa}$ (or $0.004 \mathrm{bar}$ ), which would not bring about any gas vesicle collapse in this organism (see below). Using this method it was possible to investigate the state of buoyancy at frequent intervals with little danger of the buoyancy changing during the assay.

Fig. 1 shows the result of experiments in which the changes in buoyancy state of different cultures were investigated with the centrifuged Microslide, following a light intensity shift from about 10 to $120 \mu \mathrm{mol} \mathrm{m}^{-2} \mathrm{~s}^{-1}$. In five separate experiments it was found that the time taken for $50 \%$ of the cells to lose their buoyancy varied between about 1 and $5 \mathrm{~h}$ (see Table 1), presumably depending on the initial buoyancy and physiological state of the culture. Causes of the buoyancy change were investigated as follows.

\section{Pressure required to collapse gas vesicles}

The critical pressure distribution of gas vesicles and the light-stimulated changes in cell turgor pressure were investigated in experiments I-IV; similar results were obtained each time. Fig. 2 shows the collapse-pressure curves of gas vesicles in cells of Microcystis used in experiment III. The curve obtained with cells suspended in $0.5 \mathrm{M}$-sucrose shows the actual critical pressure distribution, with the impinging turgor pressure removed: the critical pressure ranged from 0.6 to $1 \cdot 1 \mathrm{MPa}$ with the pressure causing $50 \%$ collapse (the median critical pressure) occurring at $0.75 \mathrm{MPa}(7.5 \mathrm{bar})$. There was no significant change in the collapse-pressure curve, with the cells in sucrose, after exposure to high light intensity $\left(160 \mu \mathrm{mol} \mathrm{m}^{-2} \mathrm{~s}^{-1}\right.$ for $\left.5 \cdot 3 \mathrm{~h}\right)$.

The collapse-pressure curve of gas vesicles in turgid cells, suspended in culture medium, initially centred about a median critical pressure of $0.48 \mathrm{MPa}$; the difference between the critical pressures in cells suspended in medium with and without sucrose gives a measure of the turgor pressure (Walsby, 1971, 1980), which is $0.27 \mathrm{MPa}$ at this position on the curve. After $1 \cdot 1 \mathrm{~h}$ exposure to high light intensity the median critical pressure had fallen to $0.43 \mathrm{MPa}$, and after $5.4 \mathrm{~h}$ it was $0.38 \mathrm{MPa}$, indicating that the turgor pressure had risen from $0.27 \mathrm{MPa}$ to 0.32 and then $0.37 \mathrm{MPa}$. The turgor differences indicated at the $50 \%$ collapse pressure are about $0.02 \mathrm{MPa}$ less than differences at the top of the curves in Fig. 2 ; the slight decrease in cell volume resulting from gas vesicle collapse causes the turgor pressure to drop by an amount determined by the elastic modulus of the cell (Walsby, 1980).

It is clear from the curves in Fig. 2 that the turgor pressure rise was insufficient to bring about collapse of gas vesicles; the curve for turgid cells after $5.4 \mathrm{~h}$ at high light indicates that a further rise exceeding $0.1 \mathrm{MPa}$ would have been needed to bring about any spontaneous collapse. It is therefore concluded that the turgor rise merely coincides with buoyancy loss and does not cause it by collapsing gas vesicles in this strain. 


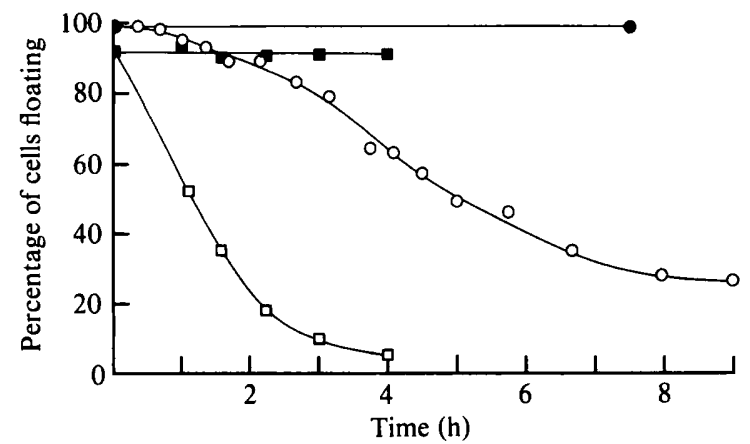

Fig. 1. Changes in percentage of cells floating with time after transfer to high light intensity. Experiment I: $\square$, high light intensity; $\square$, low light intensity. Experiment II: $O$, high light intensity; , low light intensity.

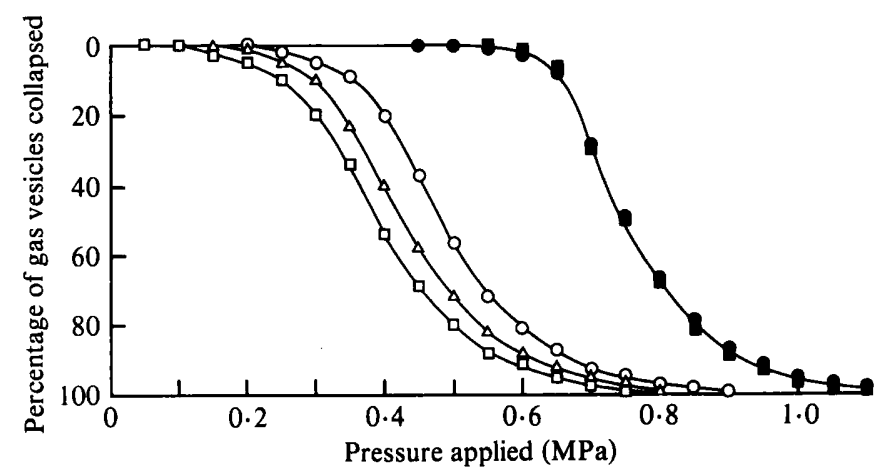

Fig. 2. Collapse of gas vesicles with pressure in cells suspended in $0.5 \mathrm{M}$-sucrose to remove turgor pressure (filled symbols) and turgid cells suspended in culture medium (open symbols). $\bigcirc$, $\bigcirc$, Before increase in light intensity; $\triangle, 1.1 \mathrm{~h}$ after increase in intensity; $\square, \square, 5.4 \mathrm{~h}$ after increase. Experiment III, conditions as Table 1 .

\section{Table 1. Changes in buoyancy state of Microcystis cells after exposure to high light intensity}

Cells grown at a photon flux density of $8-15 \mu \mathrm{mol} \mathrm{m}^{-2} \mathrm{~s}^{-1}$ were transferred to $100-150 \mu \mathrm{mol} \mathrm{m}^{-2} \mathrm{~s}^{-1}$ for the time shown.

\begin{tabular}{|c|c|c|c|c|}
\hline \multirow[b]{2}{*}{ Expt } & \multicolumn{2}{|c|}{$\begin{array}{l}\text { Percentage of } \\
\text { cells floating }\end{array}$} & \multicolumn{2}{|c|}{ Time (h) at: } \\
\hline & Initial & Final & $50 \%$ floating & Final count \\
\hline I & 92 & 6 & $1 \cdot 1$ & $4 \cdot 0$ \\
\hline II & 99 & 28 & 5.0 & 8.0 \\
\hline III & 79 & 17 & 1.5 & $5 \cdot 5$ \\
\hline IV & 87 & 24 & 2.8 & 5.6 \\
\hline V & 70 & 23 & $2 \cdot 5$ & 6.0 \\
\hline
\end{tabular}

The median critical pressures of gas vesicles in the other strains of Microcystis are indicated in Table 2. They range from 0.66 to $0.75 \mathrm{MPa}$. It is just possible that regulation of gas vesicles by turgor pressure might occur in the strains with the lower critical pressures but this needs to be demonstrated; in Anabaena flos-aquae, where regulation by turgor occurs, the median critical pressure is even lower, 0.60 MPa (Walsby, 1980). 
Table 2. Median critical pressures of gas vesicles in various strains of Microcystis

Measurements were made with the cells suspended in culture medium containing $0.5 \mathrm{M}$-sucrose to remove cell turgor pressure.

\begin{tabular}{lc}
\multicolumn{1}{c}{$\begin{array}{c}\text { Strain* } \\
\text { BC 84/1 }\end{array}$} & $\begin{array}{c}\text { Median critical pressure } \\
(\mathrm{MPa})\end{array}$ \\
PCC 7806 & 0.75 \\
UV 001 & 0.70 \\
UV 006 & 0.66 \\
UV 009 & 0.74 \\
UV 010 & 0.67 \\
Blelham Tarn & 0.68 \\
Westfield College & 0.74 \\
* BC, Bristol Cyanobacteria Collection; PCC, Pasteur Culture Collection; UV, University of Bloemfontein.
\end{tabular}

\section{Buoyancy change on collapsing gas vesicles}

After collapsing all of the gas vesicles by application of $1.4 \mathrm{MPa}$ pressure all of the cells of Microcystis strain BC 84/1 sank in the centrifuged Microslide. This demonstrated that the gas vesicles were responsible for providing the buoyancy of the floating cells. Samples of the culture (experiment II) grown at low light intensity, in which most of the cells were initially buoyant, were exposed to pressures of $0,0.35,0.40,0.45,0.5$ and $1.2 \mathrm{MPa}$ and the proportions of sinking and floating cells were measured on the Microslide (Fig. $3 a$ ). The percentage of gas vesicles remaining after each pressure treatment was determined from the collapse-pressure curve (e.g. Fig. 2 for experiment III). From these results the relationship between buoyancy state and gas vesicle content could be determined (see Fig. $3 b$ ) and it was demonstrated that in this sample $52 \%$ of the gas vesicles had to be collapsed for $50 \%$ of the cells to sink. The pressure (in addition to cell turgor pressure) that was required to collapse this proportion of the gas vesicles was $0.42 \mathrm{MPa}$ (Fig. $3 a$ ). This is much higher than any rise in turgor pressure that occurred, and confirms that the loss of buoyancy could not be caused by the turgor-mediated collapse of gas vesicles in this strain of Microcystis.

In the following experiment (III) it was necessary to collapse only $18 \%$ of the gas vesicles to cause $50 \%$ of the cells to sink (Fig. $3 b$ ); initially, only $84 \%$ of the cells were buoyant in this culture and evidently in those cells that did float the margin of buoyancy must have been less than in experiment II. Even so, a pressure of $0.39 \mathrm{MPa}$ was required to cause $50 \%$ sinking (Fig. $3 a$ ) and this is still much more than was generated by the rise in turgor pressure.

\section{Changes in gas vesicle volume}

Although it had been established that gas vesicles could not have been collapsed by turgor pressure the possibility remained that they might have been destroyed by some other process, such as enzymic digestion of the gas vesicle protein. This has been suggested as a possible means of gas vesicle regulation in other organisms (Buckland \& Walsby, 1971) but has not been demonstrated directly. In the five experiments performed to investigate buoyancy changes (Table 1) we therefore also measured the volume of gas vesicle gas space per $\mathrm{ml}$ of culture using the compression tube, before and after increasing the light intensity. As indicated in Table 3, no significant loss of gas vesicle space was detected in any of these experiments. In one of the experiments, III, it was calculated from data given in Table 1 and Fig. 3(b) that if no changes had occurred in other cell constituents it would have been necessary for $39 \%$ of the gas vesicles to have been collapsed to account for the observed buoyancy change (to $17 \%$ floating). This proportion, equivalent to $20.4 \mathrm{nl}$ gas space per ml (Table 3) is 15 times greater than the $95 \%$ confidence limit on the measurement, and would certainly have been detected.

Although no loss of gas vesicle space accompanied the light intensity increase, the results in Table 3 indicate that there had not been any significant increase in gas vesicles during the period of any of the experiments. However, during the relatively short time period of these experiments 

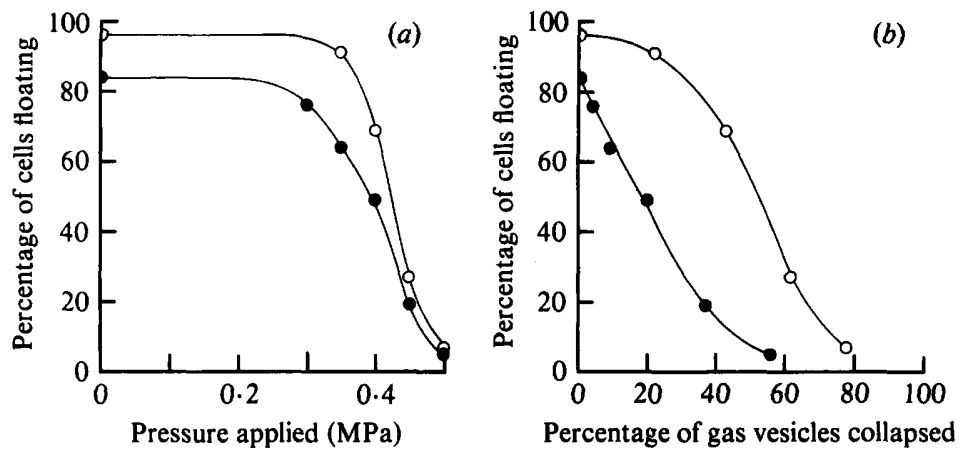

Fig. 3. Proportions of cells floating, after collapsing various proportions of the gas vesicles with pressure, in experiments II $(O)$ and III $(O)$. (a) Percentage of cells floating versus pressure applied; $(b)$ percentage of cells floating versus percentage of gas vesicles collapsed, determined from collapsepressure curve for turgid cells, e.g. as shown in Fig. 2 for experiment III.

Table 3. Volume of gas vesicle gas space in cultures before and after exposure to high light intensity

The results show volumes of gas space in $\mathrm{nl}$ per $\mathrm{ml}$ of cell suspension; values are means of four to six measurements (with $95 \%$ confidence limits).

\begin{tabular}{|c|c|c|c|c|c|}
\hline \multirow[b]{2}{*}{ Expt } & \multicolumn{4}{|c|}{ Gas volume in culture $\left(\mathrm{nl} \mathrm{ml}^{-1}\right)$} & \multirow[b]{2}{*}{$\begin{array}{l}\text { Time } \\
\text { (h) }\end{array}$} \\
\hline & $\begin{array}{l}\text { Initial } \\
\text { value }\end{array}$ & $\begin{array}{l}\text { After high } \\
\text { intensity }\end{array}$ & $\begin{array}{c}\text { After low } \\
\text { intensity }\end{array}$ & $\begin{array}{c}\text { Expected } \\
\text { value* }\end{array}$ & \\
\hline I & $29 \cdot 1( \pm 5 \cdot 8)$ & $29.9( \pm 2.5)$ & ND & $30 \cdot 1$ & $4 \cdot 0$ \\
\hline II & $41 \cdot 1(+1 \cdot 1)$ & $43.9(+4.0)$ & $41.7(+2.6)$ & 43.8 & 8.0 \\
\hline III & $52.4( \pm 1.4)$ & $53.4( \pm 3.6)$ & $51.9( \pm 1.4)$ & 54.8 & $5 \cdot 5$ \\
\hline IV & $50 \cdot 0( \pm 2 \cdot 5)$ & $49 \cdot 0( \pm 2 \cdot 4)$ & ND & $52 \cdot 3$ & $5 \cdot 6$ \\
\hline V & $28.5( \pm 1.4)$ & $28.6( \pm 2.6)$ & ND & 29.9 & 6.0 \\
\hline
\end{tabular}

ND, Not determined.

* The expected value is calculated as the initial value multiplied by $\mathrm{e}^{k t}$, where $k=0.00804 \mathrm{~h}^{-1}$ and $t$ is the time given in the last column.

it may not have been possible to detect the expected increase. The fastest growth rate found in the batch cultures incubated at $10 \mu \mathrm{mol} \mathrm{m}^{-2} \mathrm{~s}^{-1}$, used to produce the material for these experiments, was $k=0.00804 \mathrm{~h}^{-1}\left(\log _{\mathrm{e}}\right.$ units). If this had also been the relative rate of gas vesicle production at the start of each of the experiments, the gas vesicle content at the end of the experiments can be calculated as $G=G_{0} \mathrm{e}^{k a}$, where $G_{0}$ is the initial gas vesicle content and $t$ is the duration of the experiment (h). As shown in Table 3, only in experiment IV was the $95 \%$ confidence limit of the gas vesicle volume less than the expected value after exposure to high light intensity. In two of the other experiments ( $I$ and $V$ ) the expected value was within the $95 \%$ confidence limit of the initial value. It is therefore not possible to tell from these results whether the rate of gas vesicle production had decreased, and longer-term experiments are needed to resolve this point.

\section{Changes in cell density}

In the last four of these experiments measurements were also made of the cell densities after pressurizing to collapse gas vesicles. In each case there was a substantial rise in the excess density, in the region of $11-17 \mathrm{~kg} \mathrm{~m}^{-3}$, after the exposure to high light intensity (see Table 4). This indicates that there had been an increase in the relative amounts of cell components that were denser than water, for example protein (density $1300 \mathrm{~kg} \mathrm{~m}^{-3}$ ) or carbohydrate $\left(1600 \mathrm{~kg} \mathrm{~m}^{-3}\right)$. In two other cyanobacteria it has recently been shown that these two classes of 
Table 4. Changes in density of Microcystis cells after exposure to high light intensity

Cell densities were measured in samples transferred to high light intensity for the times given in Table 1 , and in samples kept at the original intensity.

\begin{tabular}{lccc} 
& \multicolumn{3}{c}{ Density of cells $\left(\mathrm{kg} \mathrm{m}^{-3}\right)$} \\
\cline { 2 - 4 } Expt & $\begin{array}{c}\text { Initial } \\
\text { value }\end{array}$ & $\begin{array}{c}\text { After high } \\
\text { intensity }\end{array}$ & $\begin{array}{c}\text { Kept at low } \\
\text { intensity }\end{array}$ \\
II & 1016 & 1027 & 1016 \\
III & 1021 & 1032 & 1023 \\
IV & 1021 & 1038 & 1026 \\
V & 1035 & 1048 & ND
\end{tabular}

Table 5. Changes in cell constituents and their ballast weights following exposure to high light intensity

(a) The amounts of the consituents were determined on a culture grown at an incident photon flux density of about $12 \mu \mathrm{mol} \mathrm{m}^{-2} \mathrm{~s}^{-1}$, and again after exposure to $120 \mu \mathrm{mol} \mathrm{m}^{-2} \mathrm{~s}^{-1}$ for $7 \mathrm{~h} ;(95 \%$ confidence limits are given in parentheses). (b) Ballast weight is the weight of the constituent minus the weight of water it displaces.

(a) Amounts

Dry weight $(\mu \mathrm{g})$

Protein $(\mu \mathrm{g})$

Carbohydrate $(\mu \mathrm{g})$

Other $(\mu \mathrm{g})$

Gas vesicle volume (nl)

(b) Ballast weights

Protein $(\mu \mathrm{g})$

Carbohydrate $(\mu \mathrm{g})$

Gas vesicle space $(\mu \mathrm{g})$

Total
Amount per $\mathrm{ml}$ of culture

$\begin{array}{cc}\begin{array}{c}\text { Initial } \\ \text { value }\end{array} & \begin{array}{c}\text { After high } \\ \text { intensity }\end{array} \\ 111( \pm 5) & 149( \pm 7) \\ 63( \pm 2) & 63( \pm 1) \\ 19( \pm 2) & 46( \pm 1) \\ 29 & 40 \\ 28( \pm 1) & 28( \pm 3)\end{array}$

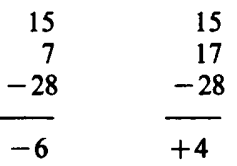

compounds provide most of the excess density (Oliver \& Walsby, 1984; Utkilen et al., 1985). We therefore determined the amounts of these substances present in samples of the culture, before and after exposure to increased light intensity (Table $5 a$ ). Protein and carbohydrate accounted for $74 \%$ of the dry weight; $7 \mathrm{~h}$ after increasing the light intensity there had been no change in protein but the carbohydrate had increased 2.4 times, accounting for the majority of the overall dry weight increase.

The ballast weights contributed by these constituents are given in Table $5(b)$; they are calculated as the weight of the constituent minus the weight of water it displaces. Thus, for protein, which has a density of about $1300 \mathrm{~kg} \mathrm{~m}^{-3}$, the $63 \mu \mathrm{g}$ would have displaced about $48 \mu \mathrm{g}$ of water, leaving a ballast weight of $15 \mu \mathrm{g}$. The ballast weight of carbohydrate was calculated assuming a density of $1600 \mathrm{~kg} \mathrm{~m}^{-3}$. The combined ballast these substances provided, $22 \mu \mathrm{g}$ per $\mathrm{ml}$ of culture, was less than the negative ballast provided by the gas vesicle gas space; $28 \mathrm{nl}$ of gas would displace a net $28 \mu \mathrm{g}$ of water. (The gas, at atmospheric pressure, weighs only $1 \mathrm{~kg} \mathrm{~m}^{-3}$, i.e. $1 \mathrm{ng} \mathrm{nl}^{-1}$.) The $26 \%$ of the dry weight unaccounted for by protein and carbohydrate would have provided some additional ballast but much of it may have been lipid, which with a density close to that of water contributes very little to the total ballast. (In Anabaena flos-aquae we have found that lipids form up to $15 \%$ of the dry weight. They are mainly mono- and digalactosyldiglycerides with a density of about $1050 \mathrm{~kg} \mathrm{~m}^{-3}$.)

After exposure to increased light intensity the ballast from the protein and carbohydrate alone exceeded the unchanged negative ballast provided by gas vesicles, and this explains why the cells lost their buoyancy and sank. 
From the data given in Table 5 it is possible to calculate the percentage of the cell protein present as gas vesicle protein. Oliver $e$ t al. (1985) have calculated that $1 \mathrm{mg}$ of gas vesicle wall material (composed entirely of gas vesicle protein) encloses $7.02 \mu 1$ of gas space in Microcystis. The $28 \mathrm{nl}$ of gas space must therefore be enclosed in $3.99 \mu \mathrm{g}$ gas vesicle protein. This represents $3.6 \%$ of the $111 \mu \mathrm{g}$ dry weight and $6.3 \%$ of the $63 \mu \mathrm{g}$ of total protein in this sample. The percentages found in Microcystis from Blelham Tarn were slightly higher than this (Oliver et al., 1985). The gas vesicle protein must therefore be one of the major cell proteins and represents a significant proportion of the cells' resources.

\section{DISCUSSION}

These studies have confirmed that some strains of Microcystis have the ability to regulate their buoyancy according to the light intensity. In strain BC 84/1 the mechanism of buoyancy change is a form of gas vesicle dilution by growth (see below) and does not involve collapse of gas vesicles by turgor pressure. The same may be true of other strains of Microcystis but the mechanism should be investigated specifically in each case.

Reynolds (1973) assumed the mechanism of buoyancy regulation in the Crose Mere population of Microcystis was by the turgor-collapse mechanism because he found a coincidental increase in turgor pressure when colonies were decreasing in buoyancy. The gas vesicles in the Crose Mere organism have a median critical pressure of $0.8 \mathrm{MPa}$ (Reynolds, 1972) and analysis of the collapse-pressure curves indicates that very high turgor pressures would be required to cause buoyancy change by the turgor mechanism; the dilution mechanism is more likely in this case. Okada \& Aiba (1983) constructed a detailed mathematical model of vertical migration by Microcystis, which was based on the assumption that buoyancy was regulated by the turgorcollapse mechanism. Their model might be applicable to other cyanobacteria that do regulate buoyancy in this way.

If the formation of surface water-blooms by Microcystis results from failure of colonies to regulate their buoyancy, as discussed by Reynolds \& Walsby (1975), understanding of the regulating mechanism would be necessary for an understanding of the water-bloom phenomenon. In a sense both of these mechanisms may depend on inevitable changes in photosynthetic products caused by the increase in light intensity. The ensuing increase in photosynthetic rate causes at least a temporary rise in the pool of low molecular weight products, which must elevate the turgor pressure. A substantial light-stimulated rise in turgor has been recorded not only in organisms that make use of the rise to collapse gas vesicles, but also in those like the red strains of Oscillatoria agardhii that do not (Utkilen et al., 1985). The essential difference between the two groups therefore lies not in the turgor rise but in whether the gas vesicles have a low enough critical pressure to be collapsed by it.

Perhaps the preferential accumulation of photosynthate in carbohydrate is another inevitable consequence of the increase in light intensity. The accumulation of storage polysaccharides is well known in higher plants and has previously been recorded in cyanobacteria (Konopka \& Schnur, 1980; Foy \& Smith, 1980). All such carbohydrates are heavy substances that will cause an increase in density of the organism. In the Microcystis strain examined here the increase in carbohydrate was sufficient by itself to negate the buoyancy provided by gas vesicles. In a red strain of Oscillatoria agardhii it contributed to the density rise though it would have been insufficient to cause buoyancy loss without the accompanying cessation of gas vesicle production (Utkilen et al., 1985). Nevertheless, in each case the buoyancy change is brought about by a change of the ratio in production of gas vesicles and other assimilates; each is an example of gas vesicle dilution by growth.

Both mechanisms are dependent on the availability of $\mathrm{CO}_{2}$ for photosynthesis during exposure to high light intensity. Dinsdale \& Walsby (1972) found that the turgor rise did not occur either when $\mathrm{CO}_{2}$ was removed from the suspending medium or in the presence of the photosynthetic inhibitor DCMU ( $N$-(3,4-dichlorophenyl)- $N^{\prime}, N^{\prime}$-dimethyl urea); photosynthetic carbon assimilation must also be required for gas vesicle dilution by growth. It does not necessarily follow, however, that the $\mathrm{CO}_{2}$ requirement will be quantitatively the same for both processes. 
It has been pointed out above that the mechanism of buoyancy regulation may not be the same in all strains of Microcystis; it is also possible that some strains of this organism are constitutionally buoyant and do not have the ability to lose this buoyancy at high light intensities, even given adequate supplies of inorganic carbon. Some strains may be adapted to survive prolonged exposure to high light intensities at the water surface (Eloff et al., 1976; Paerl et al., 1983) and if they can do so they can benefit from immediate access to $\mathrm{CO}_{2}$ diffusing in from the atmosphere (Walsby, 1970; Paerl \& Ustach, 1982) and supplies of fixed nitrogen precipitating in rain and dust (Lewis, 1983). Finally, buoyancy changes may have other causes. A population of Microcystis in Blelham Tarn that we have recently investigated was found to sink during autumnal mixing neither by losing gas vesicles nor by gaining ballast from cell constituents; instead, it became entrapped in and weighed down by an iron-containing colloid that precipitated in the lake water when the anoxic water of the hypolimnion mixed with the aerated water of the epilimnion (Oliver et al., 1985).

This work was supported by the Natural Environment Research Council with a studentship to R. H. Thomas and a grant to A. E. Walsby. We are grateful to R. L. Oliver for advice and valuable discussion and to Miss Annette Bees for maintaining the cultures.

\section{REFERENCES}

Allison, E. M. \& W AlSBY, A. E. (1981). The role of potassium in the control of turgor pressure in a gas vacuolate blue-green alga. Journal of Experimental Botany 32, 241-249.

Armstrong, R. E., Hayes, P. K. \& Walsby, A. E. (1983). Gas vacuole formation in hormogonia of Nostoc muscorum. Journal of General Microbiology 128, 263-270.

Bowen, C. C. \& JENSEN, T. E. (1965). Blue-green algae: fine structure of the gas vacuoles. Science 147, 14601462.

BuCKLAND, B. \& Walsby, A. E. (1971). A study of the strength and stability of gas vesicles isolated from a blue-green alga. Archiv für Mikrobiologie 79, 327337.

Carmichael, W. W. (1981). The Water Environment: Algal Toxins and Health (Environmental Science Research, Vol. 20). New York: Plenum Press.

Dinsdale, M. T. \& WalsBy, A. E. (1972). The interrelations of cell turgor pressure, gas-vacuolation, and buoyancy in a blue-green alga. Journal of Experimental Botany 23, 561-570.

Eloff, J. N., Steinitz, Y. \& Shilo, M. (1976). Photooxidation of cyanobacteria in natural conditions. Applied and Environmental Microbiology 31, 119-126.

FogG, G. E. (1969). The physiology of an algal nuisance. Proceedings of the Royal Society B173, 175189.

FogG, G. E. \& WalsBY, A. E. (1971). Buoyancy regulation and the growth of planktonic blue-green algae. Mitteilungen der internationale Vereinigung für theoretisch und angewandte Limnologie 19, 182-188.

FoY, R. H. \& SMITH, R. V. (1980). The role of carbohydrate accumulation in the growth of planktonic Oscillatoria species. British Phycological Journal 15, 139-150.

GANF, G. G. (1974). Diurnal mixing and the vertical distribution of phytoplankton in a shallow equatorial lake (Lake George, Uganda). Journal of Ecology 62, 611-629.

GaNF, G. G. \& Oliver, R. L. (1982). Vertical separation of light and available nutrients as a factor causing replacement of green algae by blue-green algae in the plankton of a stratified lake. Journal of Ecology 70, 829-844.

Grant, N. G. \& Walsby, A. E. (1977). The contribution of photosynthate to turgor pressure rise in the planktonic blue-green alga Anabaena flosaquae. Journal of Experimental Botany 28, 409-415.

Herbert, D., Phipps, P. J. \& Strange, R. E. (1971). Chemical analysis of microbial cells. Methods in Microbiology 5B, 209-344.

KLEBAHN, H. (1895). Gasvakuolen, ein Bestandteil der Zellen der wasserblütebildenden Phycochromaceen. Flora (Jena) 80, 241-282.

KONOPKA, A. \& SchNUR, M. (1980). Effect of light on macromolecular synthesis in cyanobacteria. Microbial Ecology 6, 291-301.

Konopka, A., Brock, T. D. \& Walsby, A. E. (1978). Buoyancy regulation by planktonic blue-green algae in Lake Mendota, Wisconsin. Archiv für Hydrobiologie 83, 524-537.

KRUGer, G. H. J. \& ElofF, J. N. (1977). The influence of light intensity on the growth of different Microcystis isolates. Journal of the Limnological Society of South Africa 3, 21-25.

LeHMANN, H. \& JosT, M. (1971). Kinetics of the assembly of gas vacuoles in the blue-green alga Microcystis aeruginosa Kütz. emend. Elenkin. Archiv für Mikrobiologie 79, 59-68.

LEHMANN, H. \& WIENCKE, C. (1980). Disappearance of gas vacuoles in the blue-green alga Microcystis aeruginosa. Plant, Cell and Environment 3, 319-324.

LEWIS, W. M., JR (1983). Interception of atmospheric fixed nitrogen as an adaptive advantage of scum formation in blue-green algae. Journal of Phycology 19, 534-536.

OKaDA, M. \& AIBA, S. (1983). Simulation of waterbloom in a eutrophic lake. II. Reassessment of buoyancy, gas vacuole and turgor pressure of Microcystis aeruginosa. Water Research 17, 877-882. Oliver, R. L. \& W ALSBY, A. E. (1984). Direct evidence for the role of light-mediated gas vesicle collapse in 
the buoyancy regulation of Anabaena flos-aquae (cyanobacteria). Limnology and Oceanography 29, 879-886.

Oliver, R. L., Kinnear, A. J. \& Ganf, G. G. (1981). Measurements of cell density of three freshwater phytoplankters by density gradient centrifugation. Limnology and Oceanography 26, 285-294.

Oliver, R. L., Thomas, R. H., Reynolds, C. S. \& WALSBY, A. E. (1985). The sedimentation of buoyant Microcystis colonies caused by precipitation with an iron-containing colloid. Proceedings of the Royal Society (in the Press).

PAerl, H. W. \& UstaCh, J. F. (1982). Blue-green algal scums: an explanation for their occurrence during freshwater blooms. Limnology and Oceanography 27, 212-217.

Paerl, H. W., Tucker, J. \& Bland, P. T. (1983). Carotenoid enhancement and its role in maintaining blue-green algal (Microcystis aeruginosa) surface blooms. Limnology and Oceanography 28, 847-857.

REYNOLDS, C. S. (1972). Growth, gas vacuolation and buoyancy in a natural population of a planktonic blue-green alga. Freshwater Biology 2, 87-106.

REYNOLDS, C. S. (1973). Growth and buoyancy of Microcystis aeruginosa Kütz. emend. Elenkin in a shallow eutrophic lake. Proceedings of the Royal Society B184, 29-50.

ReYNolds, C. S. \& Rogers, D. A. (1976). Seasonal variations in the vertical distribution and buoyancy of Microcystis aeruginosa Kütz. emend. Elenkin in Rostherne Mere, England. Hydrobiologia 48, 17-23.

ReYNoldS, C. S. \& Walsby, A. E. (1975). Waterblooms. Biological Reviews 50, 437-481.

Reynolds, C. S., Jaworski, G. H. M., CMiech, H. A. \& LeEDALE, G. F. (1981). On the annual cycle of the blue-green alga Microcystis aeruginosa Kütz. emend. Elenkin. Philosophical Transactions of the Royal Society B293, 419-477.

RipPKa, R., Deruelles, J., Waterbury, J. B., Herdman, M. \& Stanier, R. Y. (1979). Generic assignments, strain histories and properties of pure cultures of cyanobacteria. Journal of General Microbiology 111, 1-61.

Stanier, R. Y., Kunisawa, R., Mandel, M. \& CohenBAZIRE, G. (1971). Purification and properties of unicellular blue-green algae (order Chroococcales). Bacteriological Reviews 35, 171-205.

Utkilen, H. C., Oliver, R. L. \& Walsby, A. E. (1985). Buoyancy regulation in a red Oscillatoria unable to collapse gas vacuoles by turgor pressure. Archiv für Hydrobiologie 102, 319-329.

WALSBY, A. E. (1970). The nuisance algae: curiosities in the biology of planktonic blue-green algae. Water Treatment and Examination 19, 359-373.

WALSBY, A. E. (1971). The pressure relationships of gas vacuoles. Proceedings of the Royal Society B178, 301326.

WALSBY, A. E. (1972). Structure and function of gas vacuoles. Bacteriological Reviews 36, 1-32.

WALSBY, A. E. (1973). A portable apparatus for measuring relative gas vacuolation, the strength of gas vacuoles, and turgor pressure in planktonic bluegreen algae and bacteria. Limnology and Oceanography 18, 653-658.

WALSBY, A. E. (1978). The properties and buoyancyproviding role of gas vacuoles in Trichodesmium Ehrenberg. British Phycological Journal 13, 103-116.

WaLSBY, A. E. (1980). The water relations of gasvacuolate prokaryotes. Proceedings of the Royal Society B208, 73-102.

WaLSBY, A. E. (1982). The elastic compressibility of gas vesicles. Proceedings of the Royal Society B216, 355-368.

Walsby, A. E. \& Booker, M. J. (1980). Changes in buoyancy of a planktonic blue-green alga in response to light intensity. British Phycological Journal 15, 311-319.

W AlsBy, A. E., UtKilen, H. C. \& Johnsen, I. J. $(1983 a)$. Buoyancy changes of a red coloured Oscillatoria agardhii in Lake Gjersjøen, Norway. Archiv für Hydrobiologie 97, 18-38.

Walsby, A. E., Van RiJn, J. \& Cohen, Y. (1983b). The biology of a new gas-vacuolate cyanobacterium, Dactylococcopsis salina sp. nov., in Solar Lake. Proceedings of the Royal Society B217, 417-447.

WOLFF, D. A. (1975). The separation of cells and subcellular particles by colloidal silica density gradient centrifugation. Methods in Cell Biology 10, 85-104. 